\title{
BROWSE SHRUBS FOR NEW ZEALAND
}

\author{
G. D. HILL \\ Department of Plant Science, Lincoln College
}

DURing 1919 and 1920, Cockayne (1919a, b, c; 1920a, b, c) published a series of papers on the montane tussock-grasslands of New Zealand. Then, as now, there were worries about overgrazing because carrying capacity had declined from one sheep per 1.2 ha, to one 'sheep per 2 ha (Cockayne, 1919a). As part of his work Cockayne observed plant species eaten by sheep at Hanmer during January (Cockayne, 1919b) and September 1919 at the same site (Cockayne, 1920b). On both occasions stocking rate was very heavy for the duration of the observation period. In January, 281 rams grazed the area for nine days and in September it was grazed by 645 hoggets for five days. As the total area was slightly more than IO ha it is not surprising that Cockayne $(1920 \mathrm{~b})$ commented after the second grazing that in places "the grass was cropped es closely as if it had been mown with a scythe. ..."

The interesting point that emerged from this work was the list and order of species eaten. Among shrubs and trees growing on the site, those readily eaten by sheep were Alnus glutinosa, Carmickaelia subulata, Cytisus scoparius, and Salix fragilis (Cockayne, 1919b, 1920b).

In 1947 Allan drew attention to Cockayne's work. He suggested that in view of it, and the high reputation of Cytisus monspessulanus and $C$. stenopetalus in the Canary Islands, and the naturalization of these species and $C$. proliferus in New Zealand, that members of the genus Cytisus should be evaluated in grazing experiments. Allan's suggestion is still waking to be investigated.

In the foreword to the I.A.B. publication on The $U$ se and $M$ isuse of Shrubs and Trees us Fodder it is suggested that more animals depend upon shrubs and trees for their survival than on conventional grass legume pastures (I.A.B., 19471. Perhaps it is time foa grassland workers to investigate the potential of this type of forage plant in New Zealand. It is not suggested that shrubs and trees replace conventional ryegrass/white clover pasture on flat land, but they be used to increase production on low-producing hill country. 
Most abstracted papers in a bibliography on productivity of browse plants refer to work in semi-arid regions of Australia, Russia, South Africa and the United States (C.A.B., 1967) . Commonly used genera in these countries were Artemisia, A triplex, Eu rotia, Gleditschia, Kochia, Prosopis, and Salix. In Bulgaria species of Fagus, Populus and Quercus are all browsed (Radkov, 1964), while in Japan Cassia mimosoides is used in conjunction with European-type grasses (Sekizuka, 1960).

A more recent and cowprehensive review of the potential of shrubs throughout the world is contained in the proceedings of an international symposium held at Logan, Utah, in 1971 (McKell et al., 1972) . Although the symposium covers many aspects of the biology and utilization of shrubs it deals extensively with their use for grazing, and their physiological advantages in arid situations. There are, therefore, a wide range of shrub and tree species b\&g used for grazing in other parts of the world which are suitable for investigation in the New Zealand environment.

Methods of establishment, utilization and the management of shrubs and trees for grazing on hill country would appear to be the major areas requiring research. At present, work in the tropics on use of browse shrubs is apparently ahead of that in temperate regions. (This may be due to the conservative nature of temparate pasture workers.) In Hawaii graziers have been utilizing the tree legume, Leucaena leucocephala in pastures since 1915 (Takahashi and Ripperton, 1949). The somewhat smaller legume, Desmodium canum, is also an important component in Hawaiian pastures (Younge et al., 1964).

In the U.S. Virgin Island's trials with tropical woody browse legume's gave average dry matter yields ranging from 13500 to $16600 \mathrm{~kg} / \mathrm{h}$ a per annum. Yield followed rainfall closely and rose from $6000 \mathrm{~kg}$ when rainfall was $498 \mathrm{~mm}$ to $30000 \mathrm{~kg}$ at $1224 \mathrm{~mm}$ in the best producer of the trial (Oakes and Skov, 1962). More recent Hawaiian work on Leucaena leucocephala has suggested a potential yield of $38000 \mathrm{~kg} / \mathrm{ha}$ of dry matter per annum with a crude protein content of $25 \%$ (Brewbaker et al., 1972). Hill (1969), in cutting trials in the New Guinea lowlands, has obtained a similar yield of dry matter $(42000 \mathrm{~kg})$ from the El Salvador strain of the same species.

In Brazil, R. von Schaaffhausen (pers. comm.) has obtained liveweight gains of $0.5 \mathrm{~kg} /$ day with Zebu steers grazing the legume Cajanus cajan during a five-month drought.

In a more temperate region, the Limpopo Valley of South Africa which has an annual rainfall of $279 \mathrm{~mm}$ and a tempera- 
ture range of -1 to 43" C, Cerafonia siliqua and Prosopis juliflora are being used for soil conservation and provision of food foa livestock. Production of edible pods commences four to six years after planting end may reach $50000 \mathrm{~kg}$ edible beans per hectare per annum (Sholto-Douglas, 1967). Ceratonia siliqua was introducad into New Zealand in 1917, and thrives in the warmer parts of the North Island (Allan, 1947).

In Chile another member of the genus Prosopis, P. tamarugo, is grown in the Atacama Desert in salt pans. Trees are planted at 100 to $120 /$ ha and sheep graze fallen or fresh leaf and pods. Carrying capacity increases with age of the stand from one ewe per hectare after five years to an estimated ten to twelve per hectare at 25 years (Kirby, 1972). This species was introduced into New Zealand by Lincoln College in 1973 for evaluation in South Island hill country. W. R. Sykes (pers. comm.) considers that it will probably not survive because of frost damage.

Sholto-Douglas (1972a, b) has reviewed tree crops and considers the following additional genera have species suitable for livestock feeding in temperate regions: Acer, thornless cultivars of Crafaegus, and Morus.

Because shrubs and 'trees are grazed by stock it does not necessarily indicate that they are of high nutrient quality. Russell (1947) gives the proximate analysis and mineral composition of 894 samples from shrubs and trees and the digestibility coefficients of about 120 . The list is obviously too long to reproduce here and Table 1 shows values for a few selected species that could probably be utilized in New Zealand.

TABLE 1: PROXIMATE COMPOSITION OF SOME TEMPERATE BROWSE PLANTS

(after Russell, 1947)

\begin{tabular}{lcccccc}
\hline & & \multicolumn{5}{c}{ \% Dry Matter } \\
\cline { 3 - 7 } \multicolumn{1}{c}{ Species } & $\begin{array}{c}\text { Plant } \\
\text { Part }\end{array}$ & $N \times$ & $\begin{array}{c}\text { 16.25 } \\
\text { Extract }\end{array}$ & $\begin{array}{c}\text { Crude } \\
\text { Fibre }\end{array}$ \\
\hline Acer sp. & Leaf & 11.1 & 6.6 & 24.6 & 52.9 & 4.7 \\
Alnus sp. & Leaf & 21.7 & 6.0 & 17.1 & 49.3 & 5.9 \\
Betula exilis & Leaf & 15.4 & 9.4 & 18.6 & 52.1 & 4.5 \\
Eurotia lanata & Leaf + Twig & 21.9 & 2.1 & 25.3 & - & - \\
Morus alba & Leaf & 16.3 & 4.7 & 11.6 & 50.9 & 16.7 \\
Prosopis juliflora & Leaf & 19.0 & 2.9 & 21.6 & 47.9 & 2.5 \\
Quercus virginiana & Foliage & 19.2 & 1.2 & 24.2 & 50.4 & 5.0 \\
Salix babylonica & Leaf & 16.7 & 2.9 & 18.0 & 52.1 & 10.2 \\
\hline
\end{tabular}


The nutrient value of range shrubs was investigated by Dietz (1972). He found that in spring leaf crude protein levels were 13 to $22 \%$, while stems ranged from 7 to $17 \%$. By autumn protein levels in stems, at 4 to $9 \%$, were usually higher than leaves at 5 to $7 \%$. Shrubs were highly digestible when actively growing, but digestibility declined rapidly as cell walls became more lignified.

Comparing shrubs with forbs and grasses, Cook (1972) found that Colorado range shrubs at all stages of growth contained higher levels of carotene, phosphorus and digestible protein than the grass and forb components of the range flora. On the other band, they were, at all stages of growth, lower in digestible energy than the grasses and forbs. In the vegetative state, digestible enetgy was $12900 \mathrm{MJ} / \mathrm{kg}$ and by maturity this value, fell to $5500 \mathrm{M} \mathrm{J}$. Mature grass contained $9200 \mathrm{MJ} / \mathrm{kg}$. This reduction in digestible energy is probably related to the lignification discovered by Dietz (1972).

If consideration is to be given, to the use of shrubs and browse trees research will have to be initiated in this country, As many species used in other parts of the world for browsing are already in New Zealand, an obvious first step would be to investigate their potential in the New Zealand environment.

Initial investigations would probably best be conducted at a central site with good scientific back-up facilities. Observations would be required on morphology, seasonality of production, yield and suitability for grazing. Tests would also have to be conducted on digestibility, palatability, and screening for toxic principles. This sort of simple testing should allow for the selection of a few species for more intensive further testing. In the second stage of the programme establishment and management mathods would become the main factors under test. It may be that in the initial establishment of shrubs some protection frow stock and vermin will be required. Once established, the shrubs, if heavy sesd producers, could be further spread by grazing animals and water carriage, especially if initiall areas are planted near ridges.

From all this it is possible to propose an ideal browse shrub for the New Zealaad environment.

(1) It would produce large quantities of seed which for preference would be hard. This would make establishment from seed possible and cheap. 
(2) Young seedlings should not compete well with other establised plants to reduce the chances of the shrub becoming a weed.

(3) It would be a legume or other nitrogen-fixing species.

(4) As it would mainly be grazed by sheep, the ideal shrub should have a height of 1.0 to $1.5 \mathrm{~m}$ or could be kept at this height by grazing management.

(5) Would have a deep and extensive root system and thus be resistant to drought.

(6) Would be tolerant of repeated defoliation by livestock.

(7) Would produce forage of high digestibility and nutritional quality free of toxic principles.

(8) Would have a high level of dry matter production.

(9) Would tolerate winter frosting and extremes of temperature.

(10) Would tolerate low levels of phophorus and 'acid soils.

This list may seem rather limiting, but plants which fulfil most of these conditions do exist: for example, for a tropical environment, the improved South American strains of Leuceana leucocephala (Hill, 1971).

In this paper, emphasis has been placed on the potential value of browse shrubs and trees for livestock feeding. No mention has been made of the substantial soil conservation benefits that might result from the more extensive use of this type of animal feeding system in New Zealand hill country. Development of successful management systems with shrubs and trees may enable land that has been retired because of its erosion potential, to once more become productive, as is currently taking place in Israel (Naveh, 1972).

\section{REFERENCES}

Allan, H. H. 1947: In The Use and Misuse of Shrubs and Trees as Fodder: 40-56. I.A.B., Aberystwyth.

Brewbaker, J. L.; Plucknett, D. L.; Gonzales, V., 1972: Res. Bull. 166

\section{Haw aii agric. Exp. Stn}

Cockayne, L., 1919a: N.Z. Jl Agric., 18: 1-9. 1919b: N.Z. Il Agric., 18: 321-31.

1919c: N.Z. Jl Agric., 19: 129-38.

1920a: N.Z. Il Agric., 20: 82-94. 
- 1920b: N.Z. Il Agric., 20: 209-17. 192Oc: N.Z. Il Agric., 20: 337-45.

Commonwealth Agricultural Bureaux, 1967: Bibliography No. s.739.

Cook, C. W., 1972: Gen. Tech. Rep. INT-1 USDA For. Serv.: 303-10

Dietz, D. R., 1972: Gen. Tech. Rep. INT-1 USDA For. Serv.: 289-302.

Hill, G. D., 1969: M.Sc.(Agric.) thesis, Univ. Western Australia. 1971: Herb. Abstr., 41: 111-9.

Imperia1 Agricultural Bureaux, 1947: The Use and Misuse of Shrubs nnd Trees as Fodder. I.A.B., Aberystwyth.

Kirby. J. M., 1972: WId Crops, 24 (6): 296-S.

McKell, C. M.; Blaisdell, J. P.; Goodin, J. R., 1972: Gen. Tech. Rep. INT-1 USDA For. Serv.: 1-494.

Naveh, A., 1972: Gen. Tech. Rep. INT-1 USDA For. Serv.: 414-27.

Oakes, A. I.; Skov, 0., 1962: Trop. Aqric. Trin., 39: 281-7.

Radkov, D. P., 1964: Gorskostop. Nauka. Sofia, 1: 27-8.

Russell. F. C.. 1947: In The Use and Misuse of Shrubs and Trees as Fohder: 185-231. I.A.B., Aberystwyth.

Sekizuka, S., 1960: J. Kanto-Tosan agric. Exp. Stn, No, 15: 74-90.

Sholto-Douglas, J., 1967: Wld Crops, 19 (4): 20-4.

1972a: WId Crops, 24 (1): 15-9.

1972b: WId Crops, 24 (2): 86-97.

Takahashi, M.; Ripperton, J. C., 1949: Bull. 100 Hawaii agric. Exp. Stn.

Younge, 0. R.; Plucknett, D. L.: Rotar, P., 1964: Tech. Bull. 59 Hawaii agric.' Exp. Stn. 